\title{
Glaciological investigations at the Malmbjerg mining prospect, central East Greenland
}

\author{
Michele Citterio, Ruth Mottram, Signe Hillerup Larsen and Andreas Ahlstrøm
}

Meeting the technical challenges posed by the Arctic environment is a key issue in the development of Greenland's economy, particularly in the light of increasing interest in developing Greenland's mineral resources both on- and offshore. This paper describes some results of the glaciological investigations carried out at Malmbjerg.

The world-class Malmbjerg molybdenum prospect $\left(71^{\circ} 50^{\prime} \mathrm{N}, 24^{\circ} 16^{\prime} \mathrm{W}\right)$ is located in the Stauning Alper, at the confluence of Arcturus Gletscher and the larger Schuchert Gletscher (Fig. 1). The mineral occurrence was discovered in the 1950s and industrial development of the site was attempted in the following decades (Henriksen 2008), but the venture remained economically unviable, largely due to its geographical situation. However, recent technological advances and high demand on the international metal market have led to revived interest in the development of the site as an open-pit mine.

The two glaciers surrounding Malmbjerg are pivotal in the planning of the mine. In particular, surface access to the mine across Arcturus Gletscher is a prerequisite, and the effects of accumulating coarse-grained mine waste on the glacier along the eastern slope of Malmbjerg need to be investigated. Loading of the glacier by the weight of waste rock will modify the ice flow, and darkening of the glacier surface by rock dust will affect meltwater production and, through differential ablation, the elevation and morphology of the glacier surface. Clean glaciers that become covered by debris from naturally occurring rock falls exhibit a much thinner and more homogeneously distributed debris cover, but may nevertheless provide data for comparison. Finally, surge-type glaciers are known to exist in Stauning Alper (Fig. 1), and the likelihood of a surge of Arcturus and Schuchert Gletschers during the anticipated lifetime of the mine needs to be assessed.

The results discussed below are based on data from an automatic weather station (AWS) set up on Schuchert Gletscher in April 2008 by the Geological Survey of Denmark and Greenland (GEUS), and on field observations and groundpenetrating radar surveys carried out in September 2008.

Fig. 1. Topographic map of the Malmbjerg area. Contour interval 100 $\mathrm{m}$. The red circle shows the location of the planned mine. Inset map shows the location of Malmbjerg in East Greenland. Stauning Alper is located immediately to the south-west of Malmbjerg.

\section{Meteorological observations and melt modelling}

An estimate of the magnitude and regime of surface meltwater production and of ablation over the glacier surface is required to properly dimension the mine's infrastructure, to model future differential ablation under a thickening cover of dust and debris and to assess the likelihood of surges of the two glaciers. Observations from the AWS on the glacier surface allow modelling of the surface energy balance and quantifying ablation. Meltwater from the winter snow cover is important since it contributes to the total surface runoff from Arcturus Gletscher. A snow pit showed $576 \mathrm{~mm}$ water equivalent of accumulation (corresponding to winter balance) in early April 2008 at the AWS site, where the snow cover had completely melted by mid-June.

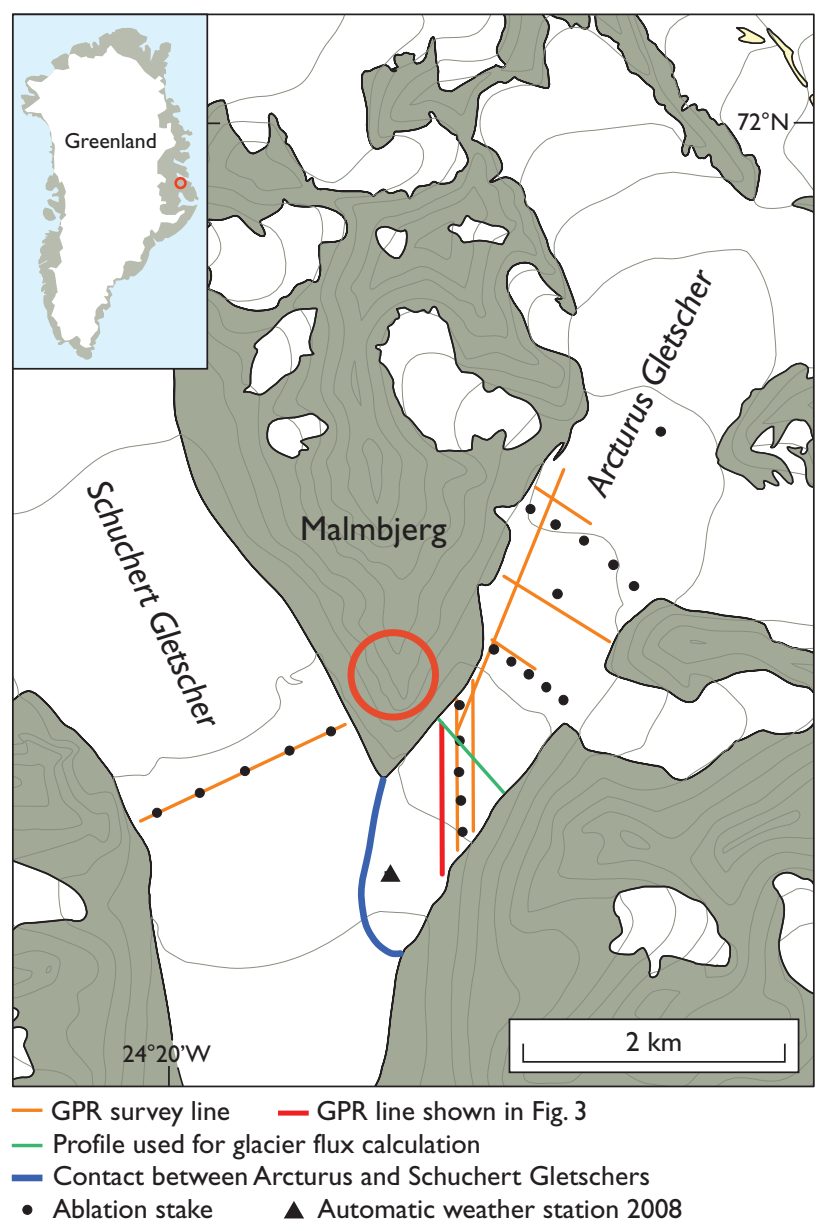



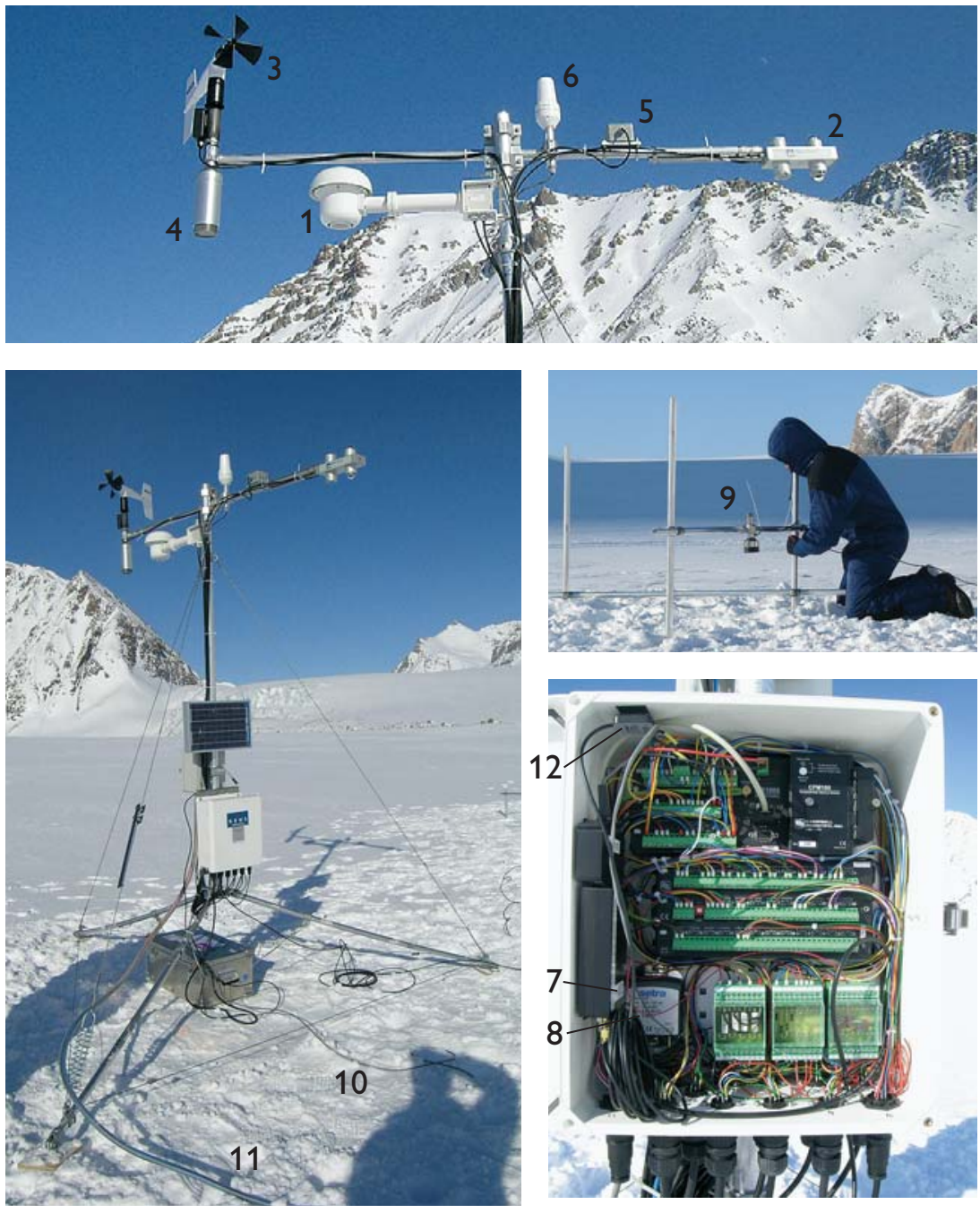

Fig. 2. The automatic weather station: 1: aspirated radiation shield for air temperature and humidity probes. 2: radiometers for shortwave and longwave incoming and outgoing radiation. 3: sensor for wind speed and direction. 4: sensor to measure snow surface level. 5: two-axes tilt sensor of the instruments boom. 6: Iridium satellite antenna. 7: Iridium satellite radio. 8: atmospheric pressure. 9: sensor to measure ice-surface level. 10: thermistor string for ice temperature (drilled into the ice). 11: ablation sensor. 12: GPS antenna.

from the area, the model was run for a range of values in order to assess the sensitivity of the model to these parameters (values of $-3.5,-0.50$ and $-0.65^{\circ} \mathrm{C} / \mathrm{km}$ and $0.0,0.5$ and $1.0 \mathrm{~kg} / \mathrm{m}^{2} / \mathrm{m}$ of elevation/year were used). Figure 3B shows the modelled cumulative ablation from May to August 2008 over the entire modelled area with a lapse rate of $-5.0^{\circ} \mathrm{C} / \mathrm{km}$ and an accumulation gradient of $0.5 \mathrm{~kg} / \mathrm{m}^{2} / \mathrm{m}$ of elevation/year. Abundant snowfall at the end of August effectively ended any further significant ablation in 2008. The amount of meltwater produced in 2008 can then be deduced by integrating the model output over the glacier area of interest.
The AWS records air temperature and humidity in an aspirated radiation shield, as well as wind speed and wind direction, incoming and outgoing shortwave and longwave radiation, barometric pressure, snow depth, ice ablation and the ice-temperature profile at eight levels down to $10 \mathrm{~m}$ below the glacier surface (Fig. 2). The measured data are stored locally in the data-logger memory and are transmitted to GEUS in Copenhagen via a satellite link. The system is mounted on an aluminium tripod standing freely on the ice surface, so that the sensor height above the ice surface remains constant throughout the ablation season.

AWS data from May to August 2008 and topographic grids were used as input to the surface energy balance model of Hock \& Holmgren (2005) with hourly time-steps over a grid of 50 $\times 50 \mathrm{~m}$ cells. Figure $3 \mathrm{~A}$ shows a good match between modelled and measured ablation at the AWS site on Arcturus Gletscher, where the surface roughness length for wind speed over ice was set to $1 \mathrm{~cm}$ in order to best simulate the on-site ablation measured from the snow pit. Since no field measurements of air temperature lapse rate or accumulation gradient were available

\section{Effects of future glacier surface darkening}

Deposition of rock dust derived from blasting and handling of ore and rock waste will result in darkening of the glacier surface around Malmbjerg, with local consequences for mobility across Arcturus Gletscher.

Dust accumulation reduces albedo and initially results in significantly higher ablation rates. Ablation reaches a maximum when the effective thickness of the debris layer is attained, and then gradually decreases until the same ablation rate as clean, bare ice is observed at the critical thickness. Any further thickening of the debris layer results in lower ablation rates, which become negligible under several tens of centimetres or a few metres. Østrem (1959) first established an empirical relationship between ablation rate and thickness of the debris cover (the ' $\varnothing$ strem curve'). Observed values for the effective and critical thicknesses range within $0.25-10 \mathrm{~mm}$ and $1.33-30 \mathrm{~mm}$, respectively (Kirkbride \& Dugmore 2003), with debris lithology and local climate playing significant roles. For simplicity we assumed in our model that dust 
Fig. 3. A: Measured versus modelled mass balance from April to August 2008 at the site of the automatic weather station. The last winter snow melted around day 178

B: Modelled ablation of Arcturus Gletscher and the lower part of Schuchert Gletscher. Contour interval $100 \mathrm{~m}$.

deposition will decrease exponentially with distance from the source. Ice ablation is scaled depending on local debris thickness using an assumed Østrem curve, converted into ice-thickness change and subtracted from the digital elevation model of the preceding time step. Ice dynamics are neglected on the assumption that the glacier is in steady state during the entire modelled time, i.e. emergence and submergence velocity fields remain constant. This is a significant simplification, especially since glacier dynamics will respond to the modified ablation rates on the darkened surface. However, errors due to non-steady state were assumed to vary slowly with distance on the glacier surface, and to be of tolerable magnitude given the semi-quantitative character of this analysis. Modelled results from various dust dispersal patterns show that areas with thick debris cover will become progressively raised over surrounding cleaner ice, and that the total surface meltwater production will peak after a variable number of years; from then on it will fall towards present values.

\section{Ice-radar survey and surge potential}

A glacier surge is a strong and comparatively short-lived acceleration of ice flow lasting from a few months to a few years. It is typical of some glaciers with ice dynamics that oscillate without converging to a steady state in which accumulation in the higher parts is balanced by ice flow and ablation in the lower tongue. In the lower parts of a glacier a surge may result in the ice velocity increasing by one or even two orders of magnitude, with the surface becoming heavily crevassed and the glacier terminus possibly advancing by several kilometres. During the much longer quiescent phase following a surge, the ice at lower elevations will stagnate and waste down, while new mass builds up in the accumulation zone until the next surge event. A surge of either Arcturus Gletscher or Schuchert Gletscher would cause considerable difficulties to the mining operations.

Surge-type glaciers are known from Stauning Alper (Olesen \& Reeh 1969; Jiskoot et al. 2003), and hummocky morphology with extensive ice-cored moraines suggest that both the Arcturus Gletscher and Schuchert Gletscher may be of surge type. To assess the surge potential of Arcturus
Gletscher, we estimated how the present mean-ice velocity through a given cross-section of the glacier compares to the balance velocity required in a steady state.

Profiles of Arcturus Gletscher were obtained using groundpenetrating radar (Fig. 4). Processing included migration to produce a geometrically correct representation of the subsurface. Two other features could also be mapped: the cold to temperate transition surface separating cold ice from the underlying temperate ice at the pressure melting point and an englacial meltwater channel.

Analyses based on the balance velocity have commonly compared the ice flow through a cross-section to the net balance up-flow of the cross-section, but no accumulation data are yet available for the two glaciers. We therefore compared the ice flux with the net balance down-flow of the selected cross-section. Although conceptually analogous, this method is not optimal for our purposes, since it cannot detect any mass build-up in the higher reaches of the glacier which are not balanced by the present glacier flow. However, Melvold \& Hagen (1998) observed the imbalance between mass supply by ice flow and surface net balance to be strong along the entire length of a surge-type glacier in its quiescent phase, and this adds confidence to our approach. The balance velocity calculated for Arcturus Gletscher through the section

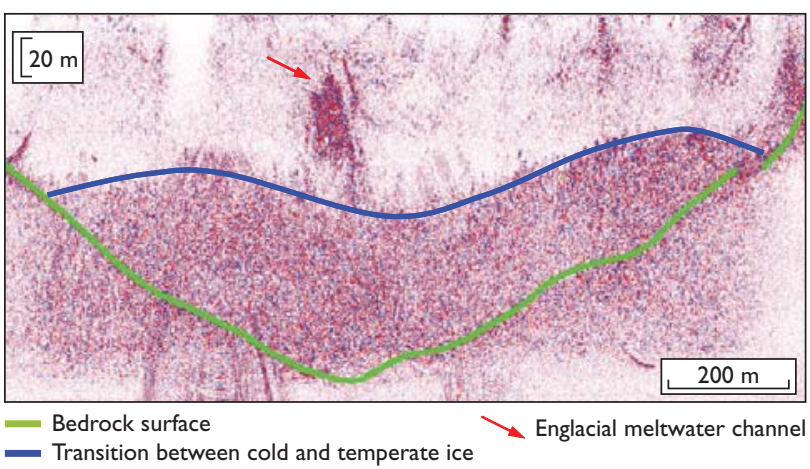

Fig. 4. Migrated ground-penetrating radar profile of Arcturus Gletscher along the path shown in Fig. 1 
marked in Fig. 1 is $18 \mathrm{~m}$ per year. This can be compared with the present-day average velocity of $22 \mathrm{~m}$ per year obtained from feature tracking on two orthophotographs from 2005 and 2007, and using theoretical results relating surface velocity with mean velocity over a cross-section of parabolic shape (Paterson 1994). Considering the uncertainties involved, we conclude that no imbalance has been detected to suggest that a surge of Arcturus Gletscher will occur in the near future. However, instead of a single year of observations, multi-year average net mass-balance data are needed to provide a more solid assessment.

\section{Accumulation of waste rock and ice deformation}

Waste-rock accumulation on the surface of Arcturus Gletscher close to the Malmbjerg slope will affect the dynamics of the glacier, but prediction of such changes and their role is a difficult task, which requires sophisticated three-dimensional numerical models. As a preliminary approach we used simple one- and two-dimensional models to calculate the rate of ice deformation under a specific load, and how this impact could be minimised. A possible similar case may be found at the Kumtor mine in the Tien Shan Mountains in Kyrgyzstan. Gold-mine waste deposited on the Davidov Glacier over a period of 15 years caused a narrowing of the effective flow area, leading to an acceleration of the confined flow unit and increased crevassing extending to the adjacent flow unit of the glacier (Bruce et al. 2008).

In the first of our simplified conceptual models we assume the glacier to be a very viscous liquid, and that the rock waste, being thicker than naturally occurring supraglacial debris, will slowly sink into the glacier at a rate controlled by the viscosity of this liquid and the dimensions and shape of the rock particles. This model is analogous to the classical high-school experiment of dropping a ball into syrup and measuring how quickly it settles in order to determine the viscosity of the fluid. The second model assumes that all ice is displaced by the rock, and that the rate of deformation depends on the applied stress, employing a non-linear flow law commonly used in numerical models of glaciers. The two simplified models have been run using the expected timing and pattern of waste-rock accumulation, the profile of the glacier bedrock, and the depth to the temperature transition surface. Several assumptions are involved, for instance concerning the applied stresses and the ice viscosity. Nevertheless, the two models can provide rough upper and lower limits to what is likely to happen and how quickly. Both models predict the highest settling velocities at the lower end of the deposit where the ice is thickest, and the fastest times to the bed (from less than a decade to a few decades) close to the Malmbjerg slope where the ice is thinner.

\section{Final remarks}

Planning mining operations at Malmbjerg must include an evaluation of the challenges posed by the glaciers that surround it. Glaciological investigations can provide useful insight into how such challenges can be dealt with as the site is being developed. At the same time, mining sites such as Malmbjerg can become case studies of great scientific interest. However, a single year of observations may not be representative of the local climate; therefore continued operation of the AWS and further surveys are required to provide a better basis for validation of the results.

\section{Acknowledgements}

This research has been funded by Quadra Mining Ltd. Jesper Kofoed from Quadra Mining and the team from MT Højgaard A/S at Malmbjerg base camp helped with all aspects of our field work.

\section{References}

Bruce, I., Redmond, D. \& Thalenhorst, H. 2008: Technical report on the 2007 year-end mineral reserves and resources, Kumtor gold mine, Kyrgyz Republic, for Centerra Gold Inc and Cameco Corporation, 162 pp. Toronto: Strathcona Mineral Services Limited.

Henriksen, N. 2008: Geological history of Greenland, 270 pp. Copenhagen: Geological Survey of Denmark and Greenland.

Hock, R. \& Holmgren, B. 2005: A distributed surface energy-balance model for complex topography and its application to Storglaciären, Sweden. Journal of Glaciology 51(172), 25-36.

Jiskoot, H., Murray, T. \& Luckman, A. 2003: Surge potential and drainagebasin characteristics in East Greenland. Annals of Glaciology 36, 142-148.

Kirkbride, M.P. \& Dugmore, A.J. 2003: Glaciological response to distal tephra fallout from the 1947 eruption of Hekla, south Iceland. Journal of Glaciology 49(166), 420-428.

Melvold, K. \& Hagen, J.O. 1998: Evolution of a surge-type glacier in its quiescent phase: Kongsvegen, Spitzbergen 1964-95. Journal of Glaciology 44(147), 394-404.

Olesen, O.B. \& Reeh, N. 1969: Preliminary report on glacier observations in Nordvestfjord, East Greenland. Rapport Grønlands Geologiske Undersøgelse 21, 41-53.

Østrem, G. 1959: Ice melting under a thin layer of moraine and the existence of ice cores in moraine ridges. Geografiska Annaler 41, 228-230. Paterson, W.S.B. 1994: The physics of glaciers, 480 pp. Oxford: Elsevier. 